\title{
KERAGAAN WARNA IKAN CLOWN BIAK (Amphiprion percula) POPULASI ALAM DAN BUDIDAYA BERDASARKAN ANALISIS GAMBAR DIGITAL
}

\author{
Ruby Vidia Kusumah", Sawung Cindelaras, dan Anjang Bangun Prasetio \\ Balai Penelitian dan Pengembangan Budidaya Ikan Hias \\ (Naskah diterima: 29 Juli 2015; Revisi final: 28 Agustus 2015, Disetujui publikasi: 2 September 2015)
}

\begin{abstract}
ABSTRAK
Penelitian ini bertujuan untuk mengkaji keragaan warna ikan clown Biak (Amphiprion percula) populasi alam dan budidaya berdasarkan analisis gambar digital sebagai dasar upaya pemuliaannya. Gambar digital diambil dari koleksi ikan clown Biak Balai Besar Perikanan Budidaya Laut Lampung, Balai Besar Penelitian dan Pengembangan Budidaya Laut Gondol, Bali; serta pengumpul ikan hias di Denpasar, Bali menggunakan kamera digital Canon EOS 600D. Pola warna dikarakterisasi secara visual terhadap variasi strip hitam dan putih pada dasar badan oranye, jenis warna dianalisis menggunakan Image 1.49 s, persentase penutupan warna dilakukan dengan Adobe Photoshop CS5. Pola warna dikarakterisasi oleh strip hitam tebal, tipis, gelap, pudar, terputus, bergabung, serta strip putih normal, pelana, spot, melebar, dan terputus. Warna hitam alam dikarakterisasi oleh hue $(\mathrm{H})$ : 300-60ㅜ, saturation (S): 8\%-56\%, brightness (B): 3\%-19\%, sedangkan budidaya H: 300-23으, S: 9\%-71\%, B: 4\%-20\%. Warna oranye alam H: $19-33^{\circ}$, S: $88 \%-98 \%$, B: 47\%-85\%, dan budidaya H: $14-29 \circ$, S: $86 \%-99 \%$, B: $38 \%-82 \%$. Warna putih alam H: $36-270$ \%; S: $1 \%-13 \%$, B: $66 \%-88 \%$, dan budidaya $\mathrm{H}$ : 0-229o, S: $0 \%-14 \%$, B: $55 \%-87 \%$. Persentase penutupan warna badan didominasi warna oranye dengan rata-rata $45 \%$ untuk populasi alam dan $57 \%$ untuk populasi budidaya. Keragaan warna ikan clown Biak dapat diarahkan pada pembentukan strain misbar, picasso, spot (domino), dan onyx. Metode analisis gambar digital sangat potensial digunakan untuk analisis keragaan warna ikan hias.
\end{abstract}

KATA KUNCI: keragaan warna, Amphiprion percula, clown Biak, analisis gambar digital, strain

ABSTRACT: Colors performance of wild and cultured population of percula clownfish (Amphiprion percula) based on digital image analysis. By: Ruby Vidia Kusumah, Sawung Cindelaras, and Anjang Bangun Prasetio

The objectives of this research is to identify the color performance of wild and cultured population of true percula clownfish (Amphiprion percula) based on digital image analysis as the basis for breeding program. The digital images were collected of the Lampung Center for Mariculture Development, Institute of Mariculture Research and Development, Gondol, Bali, and ornamental fish collectors in Denpasar, Bali used Canon EOS 600D digital camera. The color patterns were characterized visually on digital images, digital color by ImageJ 1.49s, conversion of RGB to HSB color model and the measurement of the colors covered by Adobe Photoshop CS5. Color pattern of percula clownfish are varied. The wild black color are characterized by hue $(H): 300-60^{\circ}$, saturation (S): $8 \%-56 \%$, brightness (B): $3 \%-19 \%$, and cultured by $\mathrm{H}: 300-23^{\circ}$, S: 9\%-71\%, B: 4\%-20\%. The wild orange color: H: $19-33^{\circ}$, S: $88 \%-98 \%$, B: 47\%-85\%, and cultured: H: $14-29^{\circ}$, S: 86\%-99\%, B: 38\%-82\%. Wild white color: H: 36-270; S: 1\%-13\%, B: 66\%-88\%, and cultured: H: $0-229^{\circ}$, S: $0 \%-14 \%, B: 55 \%-87 \%$. Based on the covering color percentage, clown fish body was dominated by orange color (average 57\% for cultured and 45\% for the wild). The color performance of wild and cultured of true percula clownfish selectively could be used for breeding program of misbar, picasso, spot (domino), and onyx color strains. Digital image analysis are potential for analyzed of ornamental fish color performance.

KEYWORDS: $\quad$ Amphiprion percula, true percula clownfish, colors performance, digital image analysis, strain

\# Korespondensi: Balai Penelitian dan Pengembangan Budidaya Ikan Hias. Jl. Perikanan No. 13, Pancoran Mas, Depok 14634. Indonesia. Tel.: + (021) 7520482

E-mail: rubyvkusumah@kkp.go.id 


\section{PENDAHULUAN}

Keturunan ikan clown Biak (Amphiprion percula) hasil budidaya menunjukkan degeneratif warna dengan badan berwarna pucat, pola pita putih tidak terbentuk secara sempurna, serta memiliki variasi pola warna (Kusumawati, 2010, unpublished; Setiawati et al., 2011) yang tidak terarah sehingga memengaruhi harga jualnya di pasaran. Untuk mengatasi hal tersebut, para hobbies dan breeder di dunia telah mensiasati permasalahan yang terjadi melalui upaya pemuliaan terhadap keragaan warna. Seleksi terhadap jenis, pola, hingga persentase penutupan warna telah menghasilkan berbagai strain warna ikan hias clown mulai dari black clownfish, picasso, froshbite, onyx, nebula, snowflake, snow onyx, platinum, naked, albino, davinci, fancy, wyoming white, domino, hingga xanthic (Pedersen, 2015; ORAfarm, 2014a; 2014b; Animal-world, 2015; Barrierreefaquariums, 2014; Saltwaterfish, 2014). Nilai jual ikan hias clown meningkat dengan kisaran harga antara US\$ 19,99159,99 untuk strain-strain warna tersebut di atas, sedangkan untuk pola normalnya berkisar antara US\$ 15,99-19,99 (Barrierreefaquariums, 2014; Saltwaterfish, 2014). Namun, sampai saat ini berbagai induk strain warna black clownfish hingga xanthic tersebut tidak banyak beredar di masyarakat.

Pembentukan berbagai strain baru lainnya diperlukan untuk menambah keragaman jenis dan strain (KKP, 2014) warna ikan clown yang ada. Dari sisi bisnis, upaya ini dilakukan sebagai strategi pemasaran untuk memperkaya produk, meningkatkan daya tarik dan daya saing, serta menghindari kejenuhan di tingkat konsumen. Kajian terhadap status keragaan warna populasi alam dan budidaya penting dilakukan sebagai dasar untuk mendukung upaya tersebut. Meski telah dilaporkan pada beberapa penelitian (Yasir \& Qin, 2009; 2010; Kusumawati, 2010, unpublished; Sembiring et al., 2010; Setiawati et al., 2011; Kusumawati et al., 2012; Sembiring et al., 2013), namun keragaan warna ikan clown, khususnya $A$. percula, populasi alam dan budidaya belum diketahui secara lengkap. Berbagai karakter keragaan warna, seperti jenis, pola, maupun persentase penutupan warnanya, belum dilaporkan dengan jelas.

Warna merupakan karakter penting badan ikan hias yang memberikan daya tarik (Rezende et al., 2012; Esanu et al., 2015), serta berhubungan dengan persepsi penglihatan mata manusia (Harman, 1996; Wu \& Sun, 2013). Setiap orang dapat saja memiliki persepsi yang berbeda (subyektif) terhadap suatu jenis, pola, maupun kualitas warna yang sama. Oleh karena itu, untuk mengkaji keragaan warna diperlukan suatu metode standar yang obyektif, akurat, dan mudah dilakukan (Kusumah et al., 2011; Wu \& Sun,
2013). Seiring perkembangan ilmu pengetahuan dan teknologi, analisis gambar digital hadir sebagai metode alternatif yang potensial untuk karakterisasi keragaan warna ikan hias. Menggunakan berbagai bantuan software pada komputer, keragaan warna dapat dikuantifikasi dengan mudah dalam suatu angka dan nilai digital tertentu yang sesuai penglihatan mata manusia, serta dapat dianalisis secara statistik dengan hasil yang dapat dipertanggungjawabkan secara ilmiah (Georgieva et al., 2005; Yasir \& Qin, 2009; 2010; Kusumah et al., 2011; Wu \& Sun, 2013).

Penelitian ini bertujuan untuk mengkaji keragaan warna ikan clown Biak (A. percula) populasi alam dan budidaya berdasarkan analisis gambar digital. Berdasarkan hasil penelitian ini, diharapkan dapat memberikan rekomendasi mengenai upaya pemuliaan ikan clown Biak, khususnya dalam pembentukan berbagai strain warnanya.

\section{BAHAN DAN METODE}

\section{Objek Penelitian}

Ikan clown Biak (A. percula) populasi alam dan budidaya yang menjadi objek dalam penelitian ini merupakan ikan koleksi milik Balai Besar Perikanan Budidaya Laut (BBPBL), Lampung dan Balai Besar Penelitian dan Pengembangan Budidaya Laut (BBPPBL), Gondol Bali, serta koleksi langsung dari pengumpul ikan hias di Denpasar, Bali. Ukuran ikan yang digunakan memiliki panjang total berkisar 4,7-7,6 cm (mean $=5,7 \pm 0,9 \mathrm{~cm}$ ) di mana pola warna telah terbentuk secara definitif. Jumlah sampel yang digunakan masing-masing populasi (alam dan budidaya) adalah sebanyak 30 sampel (Tabel 1). Pengambilan sampel dilakukan secara acak sederhana (simple random sampling).

\section{Keragaan Warna}

\section{Pola warna}

Setiap jenis pola warna ikan clown Biak yang terbentuk dari warna hitam, putih, dan oranye didokumentasikan menggunakan kamera digital Canon EOS 600D. Proses karakterisasi gambar digital pola warna dianalisis secara visual dengan bantuan tampilan layar komputer terhadap ukuran (tebal atau tipis), kualitas (gelap atau pudar), dan bentuk (terputus atau bergabung) pada strip warna hitam, serta bentuk normal dan tidak normal (pelana, spot, melebar, dan terputus) pada strip warna putih. Metode pengambilan foto dilakukan berdasarkan modifikasi dari Kusumah et al. (2011).

\section{Profil warna digital}

Setiap jenis warna (hitam, putih, dan oranye) dikarakterisasi secara digital berdasarkan metode 
Tabel 1. Komposisi sampel ikan clown Biak populasi alam dan budidaya yang digunakan Table 1. Sample compositions used of wild and cultured populations of percula clownfish

\begin{tabular}{lcccc}
\hline $\begin{array}{c}\text { Populasi } \\
\text { Populations }\end{array}$ & $\begin{array}{c}\text { BBPPBL Gondol } \\
\text { IMRAD Gondol }\end{array}$ & $\begin{array}{c}\text { Pengumpul } \\
\text { Collector }\end{array}$ & $\begin{array}{c}\text { BBPBL Lampung } \\
\text { LCMD Lampung }\end{array}$ & $\begin{array}{c}\text { Total } \\
\text { Total }\end{array}$ \\
\hline Alam (Wild) & 13 & 9 & 8 & 30 \\
Budidaya (Cultured) & 7 & 12 & 11 & 30 \\
\hline
\end{tabular}

Keterangan (Note):

IMRAD = Institute of Mariculture Research and Development, Gondol; LCMD = Lampung Center for Mariculture Development

Kusumah et al. (2011) menggunakan software ImageJ (Image Processing and Analysis in Java) versi $1.49 \mathrm{~s}$ (Rasband, 2015). Nilai mean RGB (Red Green Blue) hasil karakterisasi selanjutnya dikonversi pada model warna HSB (Hue Saturation Brightness) menggunakan software Adobe Photoshop CS5 Extended versi 12.0 x64 (Adobe Systems Incorporated). Kisaran nilai digital dari parameter hue ditampilkan dalam bentuk grafik yang dibuat secara manual dengan bantuan software Corel Draw X3 versi 13.0.0.576 (Corel Corporation, 2005). Sedangkan parameter saturation dan brightness ditampilkan dalam grafik boxplot menggunakan Microsoft Excel 2007 (Microsoft Corporation, 2007) berdasarkan panduan Contextures Inc. (2013). Secara konsep, model warna HSB dapat dijelaskan melalui visualisasi grafik pada Gambar 1.

\section{Persentase penutupan warna}

Persentase penutupan warna hitam, putih, dan oranye masing-masing diukur berdasarkan luasan pixel setiap jenis warna per luasan total permukaan badan ikan clown Biak (Gambar 2). Pengukuran setiap luasan pixel dilakukan menggunakan software Adobe Photoshop CS5 Extended versi 12.0 x64. Secara formulasi, persentase penutupan warna dikalkulasi dengan rumus: \% Penutupan warna $\mathrm{i}=$ (Luas pixel penu-

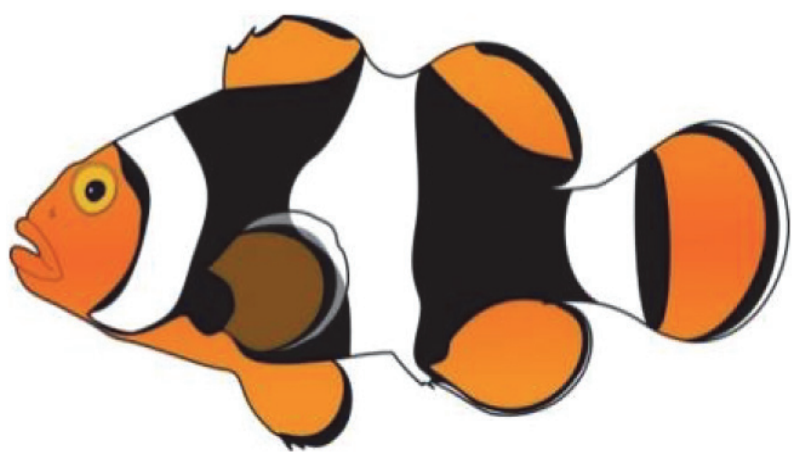

Gambar 2. Penutupan warna pada tubuh ikan clown Biak

Figure 2. Colors covered on the percula clownfish body

tupan warna i / Luas pixel penutupan total) x $100 \%$, di mana i merupakan warna hitam, putih, atau oranye.

\section{Spesifikasi komputer}

Software Adobe Photoshop CS5 Extended versi 12.0 x64 dijalankan pada sistem operasi (OS) Windows 7 Ultimate 64 bit (Microsoft Corporation, 2009) dengan spesifikasi prosesor Intel(R) Pentium(R) CPU G2010 @ 2.80GHz dan memori RAM sebesar 4 GB. Sedangkan software lainnya dapat dijalankan pada komputer dengan spesifikasi lebih rendah seperti

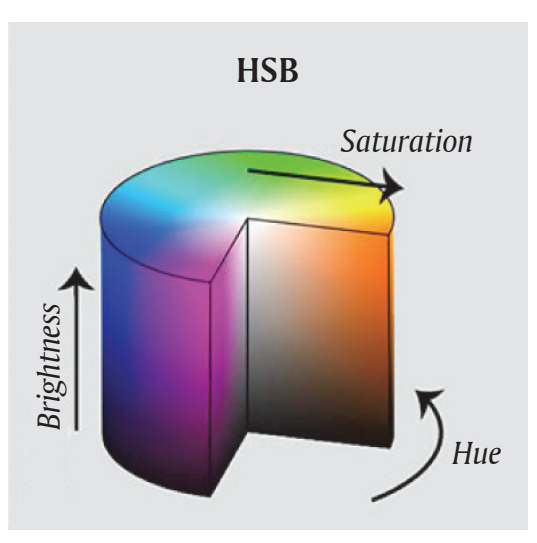

A

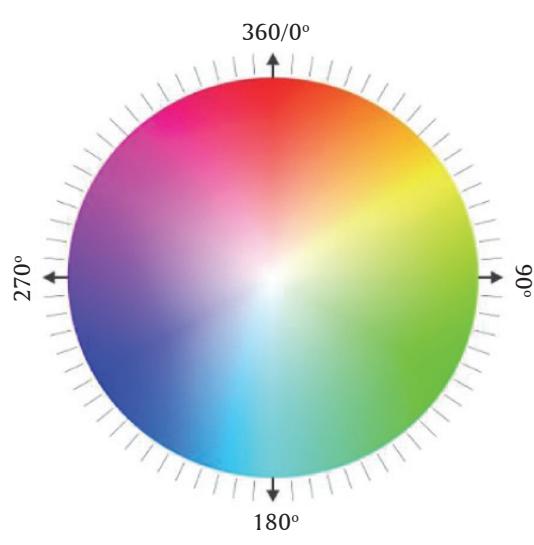

B

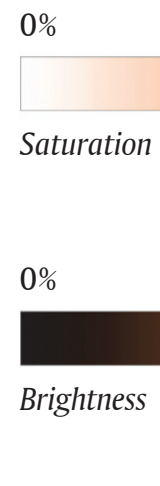

$0 \%$

$100 \%$

C

Gambar 1. Model warna HSB (Hue Saturation Brightness) (A), parameter hue (B), saturation, dan brightness (C) Figure 1. HSB (Hue Saturation Brightness) color model (A), hue parameter (B), saturation, and brightness (C) 
Netbook yang beroperasi pada Windows 7 Ultimate 32 bit dengan prosesor Intel(R) Atom(TM) CPU N570 @ $1,66 \mathrm{GHz}$ dan memori RAM 2 GB.

\section{Analisis data}

Analisis data dilakukan secara deskriptif menggunakan software Microsoft Excel 2007 terhadap jenis pola warna, persentase individu berdasarkan keragaan strip hitam dan putih, profil warna digital, serta persentase penutupan warna pada populasi alam dan budidaya ikan clown Biak. Data ditampilkan dengan tabulasi dan grafik. Perbedaan persentase penutupan warna hitam, putih, dan oranye antara populasi alam dan budidaya dilakukan dengan uji-t menggunakan Microsoft Excel 2007. Sedangkan data pencilan (outlier) dari parameter saturation dan brightness dianalisis berdasarkan pendekatan skor $\mathrm{z}$ dengan mengikuti panduan Excel Is Fun (2009).

\section{HASIL DAN BAHASAN}

\section{Variasi Pola Warna}

Pada bentuk normalnya, pola warna ikan clown Biak (A. percula) dikarakterisasi oleh warna dasar badan yang kuning-oranye dengan tiga strip putih vertikal di bagian kepala, badan, dan pangkal ekor, serta ciri khusus yang membedakan dengan $A$. ocellaris berupa warna hitam yang memenuhi sisi lateral badannya (Gambar 2). Pada kenyataannya, pola warna tersebut bukan merupakan suatu standar baku. Dari hasil pengamatan yang dilakukan, ditemukan beberapa variasi pola warna lainnya.

Gambar 3 menunjukkan keragaan pola warna ikan clown Biak alam dan budidaya. Tidak seperti ikan botia (Chromobotia macracanthus) yang hanya dibentuk oleh pita warna hitam pada dasar badannya yang kuning-oranye (Kusumah et al., 2012), pola warna ikan clown Biak terbentuk oleh strip warna hitam dan strip warna putih pada dasar badannya yang berwarna kuning-oranye. Berdasarkan Gambar 3, pola warna ikan clown Biak dikarakterisasi oleh strip hitam tebal (a$\mathrm{m}, \mathrm{o}-\mathrm{t})$, tipis $(\mathrm{n}, \mathrm{u})$, gelap $(\mathrm{a}-\mathrm{k} ; \mathrm{p}-\mathrm{s})$, pudar $(\mathrm{l}, \mathrm{m}, \mathrm{o}, \mathrm{t})$, terputus (fragmented) (b-e, g-h, j-l, n-r, t-u), bergabung (joining) (a, f, i, m, s), serta strip putih berbentuk pelana (saddle) (f-h, k-l, n, s), spot $(\mathrm{k}, \mathrm{m}, \mathrm{q}, \mathrm{u})$, terputus (fragmented) (e, h, k, p-q, t-u), dan melebar (d, g, i) dengan persentase dapat dilihat pada Tabel 2. Pola warna suatu individu ikan clown Biak dapat dibentuk oleh perpaduan dari beberapa karakter warna tersebut (Gambar 3).

Hasil yang diperoleh lebih beragam dibandingkan beberapa penelitian sebelumnya. Menurut Sembiring et al. (2013), pola warna hitam ikan clown Biak terbagi menjadi strip hitam tebal melebar (kelas I), ber- garis hitam tebal (kelas II), dan bergaris hitam tipis (kelas III). Sedangkan berdasarkan komunikasi pribadi dengan Setiawati (2014) pola warna ikan clown Biak terdiri atas strip hitam tebal, strip hitam tipis, strip hitam pudar, dan tanpa strip. Menurut ORAfarm (2014b), strain ikan clown Biak tanpa strip dikenal juga dengan nama misbar dan naked (Gambar 5). Berdasarkan hasil yang diperoleh (Gambar 3), tidak ditemukan ikan clown Biak tanpa strip. Namun beberapa individu menunjukkan strip putih yang terputus (Gambar 3e, 3h, 3k, 3p-q, 3t-u), serta ukuran strip hitam yang tipis (Gambar 3n, 3u). Kehadiran pola warna yang bervariasi ini memberikan bukti dinamisasi gen-gen pengatur ekspresi dan bentuk pola warna tersebut (Kusumah et al., 2012). Coliquehue \& Araneda (2014) menyebutkan bahwa terdapat beberapa gen yang diduga terlibat dalam perkembangan kromatofor, sintesis pigmen, dan ekspresi gen dalam produksi suatu jenis warna spesifik, serta pola warna. Pada ikan zebra (Danio sp.) dan medaka (Oryzias sp.), masing-masing memiliki 90 dan 40 gen yang mengontrol spesifikasi, proliferasi, sintasan, diferensiasi, dan distribusi kromatofor di antara prosesproses lainnya (Coliquehue \& Araneda, 2014).

Pola warna pada ikan terbentuk dari interaksi cahaya dengan pola distribusi sel pigmen (CerdaReverter et al., 2009). Menurut bentuk dasarnya, Mills \& Patterson (2009) melaporkan bahwa pola pigmentasi warna dibedakan menjadi: (a) dorsal/ventral, (b) garis (strip), dan pita (bar), serta (c) tutul (spot). Sedangkan menurut Kondo \& Shirota (2009), pola ini terbagi menjadi: (a) tutul (spot), (b) garis (strip), dan (c) polygon (contoh bentuk kebalikan dari spot). Pada ikan clown, Pederson (2015) melaporkan bahwa bentuk pola warna terjadi dikarenakan adanya pengurangan strip, strip yang melebar (over barring), strip yang solid (solid barring), bentuk spot, warna hitam di bawah putih, strip yang buram (smudgy barring), dan albino. Kondisi ini secara umum sesuai dengan hasil yang diperoleh, namun dalam penelitian ini tidak ditemukan bentuk warna yang telah solid dan albino. Secara teoritis, bentuk pola warna yang diperoleh (Gambar 3) dapat diarahkan pada perakitan strain warna picasso, spot (domino), misbar, dan onyx.

Berdasarkan Gambar 3, dapat juga dilihat bahwa jumlah bentuk pola warna populasi alam ada sebanyak sembilan tipe, sedangkan populasi budidaya sebanyak 12 tipe. Pada populasi budidaya, pola warna yang terbentuk umumnya didominasi oleh ketidaksempurnaan bentuk atau terputusnya strip warna putih, baik di bagian tengah badan maupun pangkal ekor. Kondisi yang sama juga dilaporkan Kusumawati et al. (2012) yang membagi pola warna ikan clown Biak menjadi strip putih sempurna, strip putih 

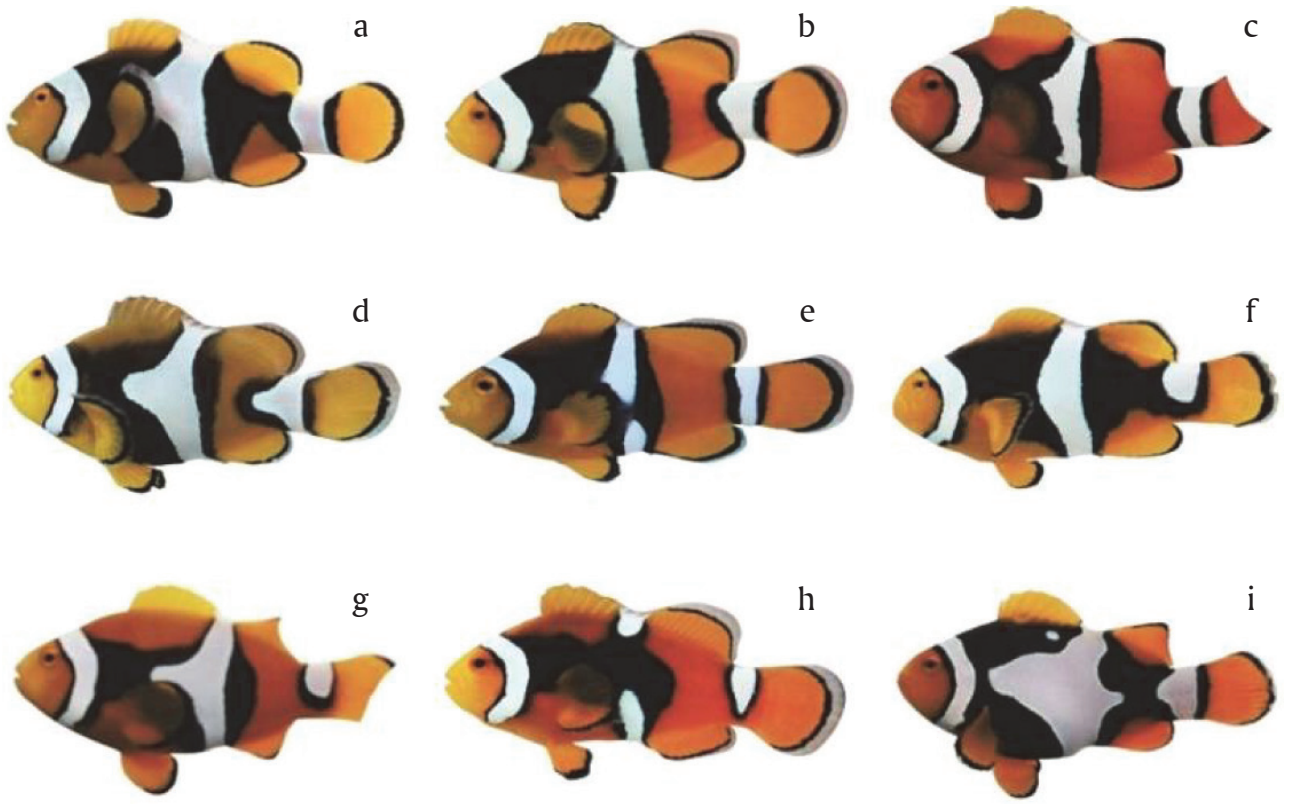

\section{BUDIDAYA (CULTURED)}
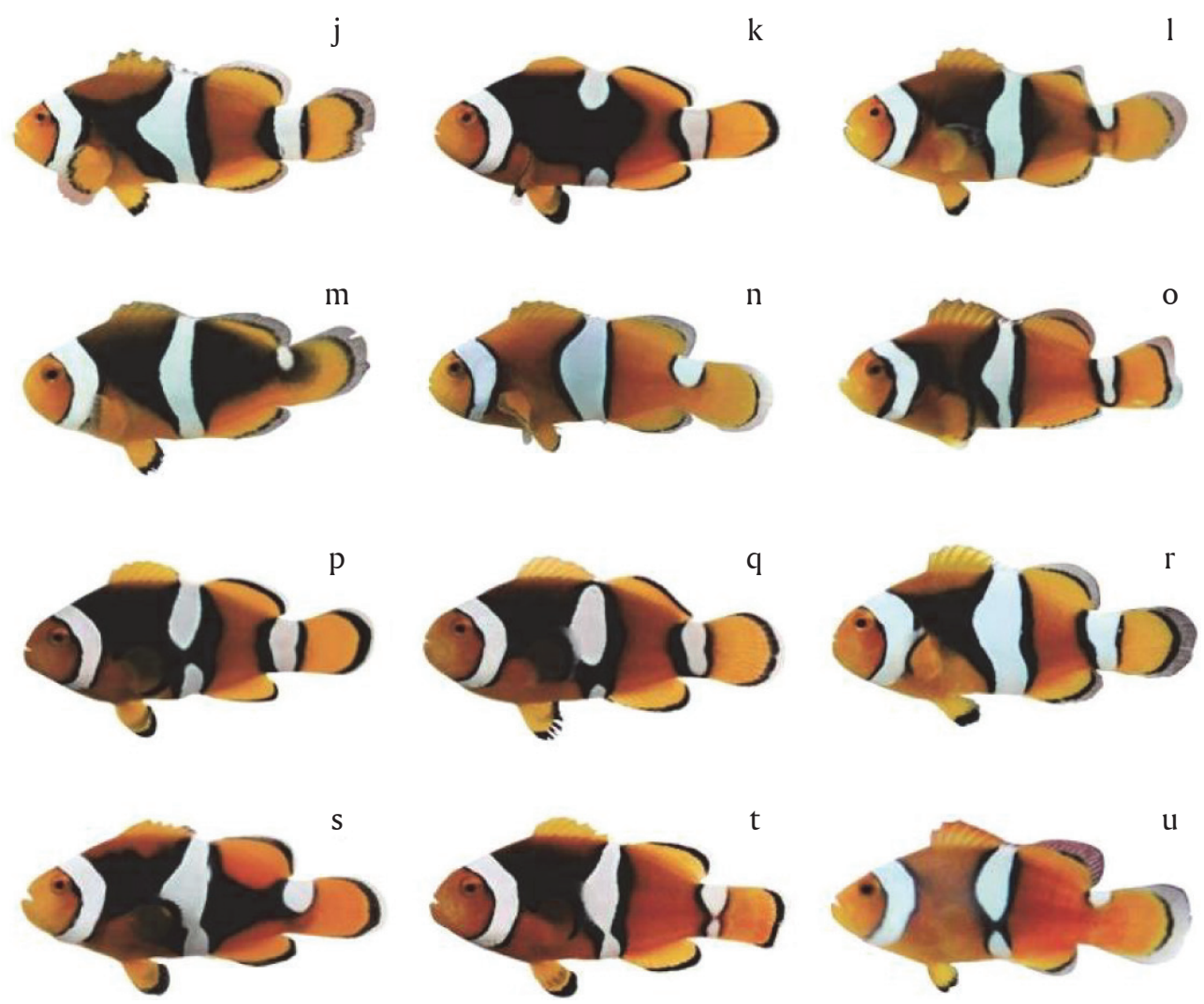

Gambar 3. Pola warna ikan clown Biak populasi alam dan budidaya: strip hitam tebal (a-m, o-t), tipis (n, u), gelap (a-k; p-s), pudar (l, m, o, t), terputus (fragmented) (b-e, g-h, j-l, n-r, t-u), bergabung (joining) (a, f, i, m, s), serta strip putih berbentuk pelana (saddle) (f-h, k-l, n, s), spot ( $\mathrm{k}, \mathrm{m}, \mathrm{q}, \mathrm{u})$, terputus (fragmented) (e, h, k, p-q, t-u), dan melebar (d, g, i)

Figure 3. Color patterns of wild and cultured of percula clownfish: thick (a-m, o-t), thin (n, u), dark (a-k; $p$-s), smudgy (l, $m, o, t)$, fragmented (b-e, g- $h, j-l, n-r, t-u)$, joining $(a, f, i, m, s)$ of black strip, and white strip with saddle shaped $(f-h, k-l, n, s)$, spot $(k, m, q, u)$, fragmented (e, $h, k, p-q$, $t-u)$, and over barring $(d, g, i)$ 
tidak sempurna, dan strip putih tidak terbentuk. Sedangkan pada populasi alam, karakter warna yang umum dimiliki setiap individu adalah strip hitam gelap dengan ukuran yang tebal (Gambar 3, Tabel 2).

Ditinjau dari jenis pola warna yang diperoleh, ikan clown Biak yang berasal dari populasi budidaya tampak menunjukkan variasi strip warna hitam yang lebih beragam dibandingkan alam. Kondisi ini dapat dilihat dari ketidakmunculan ukuran strip hitam tipis dan kualitas strip hitam pudar pada populasi alam (Gambar 3, Tabel 2). Sedangkan berdasarkan strip warna putihnya, populasi alam menunjukkan variasi yang lebih beragam dibandingkan budidaya. Kondisi ini ditunjukkan oleh ketidakmunculan strip putih dengan bentuk melebar pada populasi budidaya. Pada kondisi lainnya, strip putih populasi budidaya justru menunjukkan persentase lebih tinggi pada bentuk terputus dan spot dibandingkan populasi alam (Tabel 2).

Dibandingkan warna normalnya, kemunculan ukuran strip warna hitam yang tipis, kualitas warna hitam yang pudar, serta tingginya persentase bentuk terputus pada strip hitam dan putih menunjukkan penurunan kualitas ikan clown Biak (Kusumawati et al., 2012; Sembiring et al., 2013; Setiawati et al., 2011). Namun melalui upaya selective breeding terhadap karakter pola warna tersebut, berbagai strain warna ikan clown Biak telah dihasilkan mulai dari platinum yang menunjukkan warna putih yang solid pada ba- dannya hingga black clownfish yang menunjukkan warna hitam solid pada badannya (Gambar 5) (Pederson, 2015; ORAfarm, 2014a; 2014b; Animal-world, 2015; Barrierreefaquariums, 2014; Saltwaterfish, 2014). Tanpa selective breeding, pola warna ikan clown Biak yang dihasilkan dari upaya budidaya akan mengarah pada banyaknya variasi yang tidak terarah dengan harga jual yang murah. Kondisi ini akan menjadi permasalahan terhadap target produksi suatu strain warna yang diinginkan. Dari segi bisnis yang menuntut kualitas, kuantitas, dan kontinuitas suatu produk, kondisi ini tentunya tidak menguntungkan dikarenakan akan menghambat ketersediaan stok dan arus distribusi produk suatu strain warna tertentu saat dibutuhkan.

\section{Profil Warna Digital}

Model warna (color model) digital merupakan perwujudan warna berdasarkan fungsi matematika yang membangun suatu gambar digital. Fungsi matematika warna ini diwujudkan dalam suatu nilai tertentu tergantung model warnanya. Model warna terbagi dua, yaitu tipe yang berdasarkan atas percampuran warna dasar cahaya (RGB: Red Green Blue) dan tipe yang jenis warna, serta kecerahannya terpisah (HSB: Hue Saturation Brighness) (FuZhong dalam YongYue et al., 2009) yang lebih menyerupai persepsi penglihatan warna manusia (Georgieva et al., 2005; Wu \& Sun, 2013). Nilai warna digital yang ditampilkan dalam penelitian adalah model warna HSB.

Tabel 2. Persentase individu ikan clown Biak populasi alam dan budidaya berdasarkan keragaan strip hitam dan putih

Table 2. Individual percentage of wild and cultured of percula clownfish based on black and white strip performance

\begin{tabular}{llcc}
\hline \multicolumn{2}{c}{ Strip hitam (Black strip) } & Alam (Wild) & Budidaya (Cultured) \\
\hline \multirow{2}{*}{ Ukuran (Size) } & Tebal (Thick) & 100 & 50 \\
& Tipis (Thin) & 0 & 50 \\
\hline \multirow{2}{*}{ Kualitas (Quality) } & Gelap (Dark) & 100 & 67 \\
& Pudar (Smudgy) & 0 & 33 \\
\hline \multirow{2}{*}{ Bentuk (Shape) } & Terputus (Fragmented) & 57 & 83 \\
& Bergabung (Joining) & 33 & 17 \\
\hline \multicolumn{2}{c}{ Strip putih (White strip) } & Alam (Wild) & Budidaya (Cultured) \\
\hline \multirow{5}{*}{ Bentuk (Shape) } & 26 & 30 \\
\cline { 2 - 4 } & Normal (Normal) & & \\
\cline { 2 - 4 } & Tidak normal (Unique) & 26 & 26 \\
& - Pelana (Saddle) & 3 & 13 \\
& - Spot (Spot) & 26 & 30 \\
\hline
\end{tabular}


Gambar 4 menunjukkan profil jenis warna digital ikan clown Biak (A. percula) populasi alam dan budidaya dalam grafik hue dan boxplot saturation dan brightness. Berdasarkan hasil analisis gambar digital, jenis warna hitam (hue) populasi alam tampak lebih beragam dibandingkan populasi budidaya. Sedangkan dari parameter saturation, populasi budidaya menunjukkan variasi yang lebih beragam dibandingkan populasi alam. Berdasarkan profil parameter brightness, kedua populasi menunjukkan keragaman yang cenderung sama dengan persentase yang rendah. Menurut laporan Kusumah et al. (2011), pada ikan cupang hias (Betta splendens), warna hitam dikarakterisasi oleh nilai hue $(\mathrm{H}) 300-0^{\circ}$, saturation $(\mathrm{S}) 3 \%-58 \%$, dan brightness (B) 3\%-13\%. Dibandingkan dengan warna hitam ikan clown Biak (Gambar 4), variasi warna hue, saturation, dan brightness ikan cupang (Kusumah et al., 2011) tampak kurang beragam.

Nilai digital hitam pada color model HSB dicirikan dengan nilai parameter brightness yang sangat rendah (bergerak mendekati 0\%) (Gambar 1A dan Gambar 4). Berapapun nilai parameter hue dan saturation yang dimiliki, tinggi atau rendah, ketika memiliki kece- rahan (brightness) yang bernilai sangat rendah akan menunjukkan warna gelap (hitam) (Kusumah et al., 2011). Dari informasi yang diperoleh, jika diinterpretasikan secara visual, maka jenis warna (hue) hitam populasi alam berkisar antara warna magenta $\left(300^{\circ}\right)$ hingga kuning $\left(60^{\circ}\right)$, sedangkan populasi budidaya berkisar antara warna magenta $\left(300^{\circ}\right)$ hingga oranye $\left(23^{\circ}\right)$. Namun dikarenakan nilai digital brightness sangat rendah $(<21 \%)$, maka visualisasi yang muncul adalah warna hitam yang mengarah pada warna-warna tersebut (Gambar 4).

Jenis warna oranye populasi alam dan budidaya ikan clown Biak cenderung memiliki karakter yang sama dengan kisaran nilai hue yang sempit dan spesifik. Namun, warna oranye populasi alam bergeser ke arah warna kuning $\left(45^{\circ}\right)$ sehingga tampak menunjukkan warna yang lebih terang, sedangkan populasi budidaya bergeser ke arah merah $\left(0^{\circ}\right)$ sehingga terlihat lebih gelap. Pada spesies yang berbeda, Yasir \& Qin (2010) melaporkan bahwa kisaran nilai hue untuk ikan clown A. ocellaris berkisar antara $31^{\circ}-33^{\circ}$. Kisaran ini berbeda dibandingkan total populasi ikan clown Biak total (alam dan budidaya) yang diperoleh
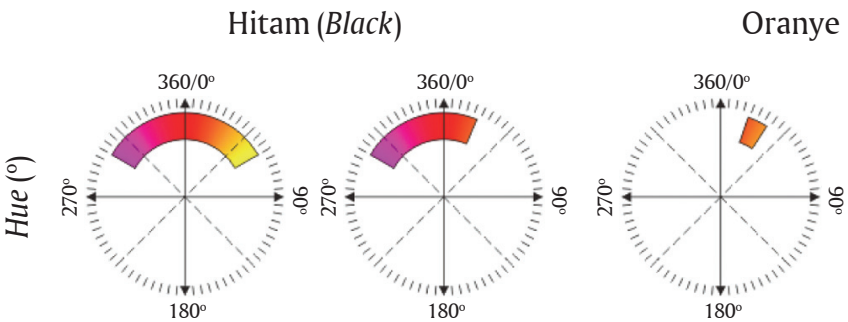

$180^{\circ}$
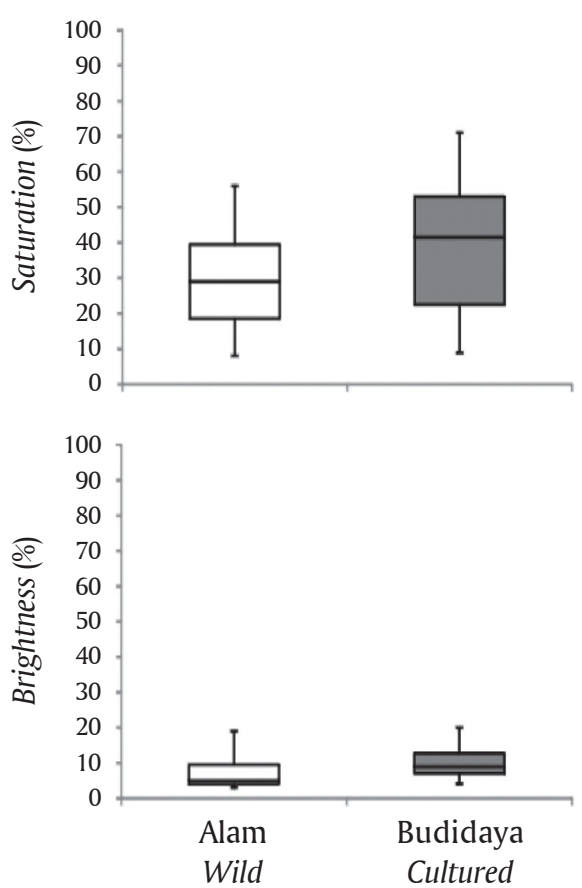
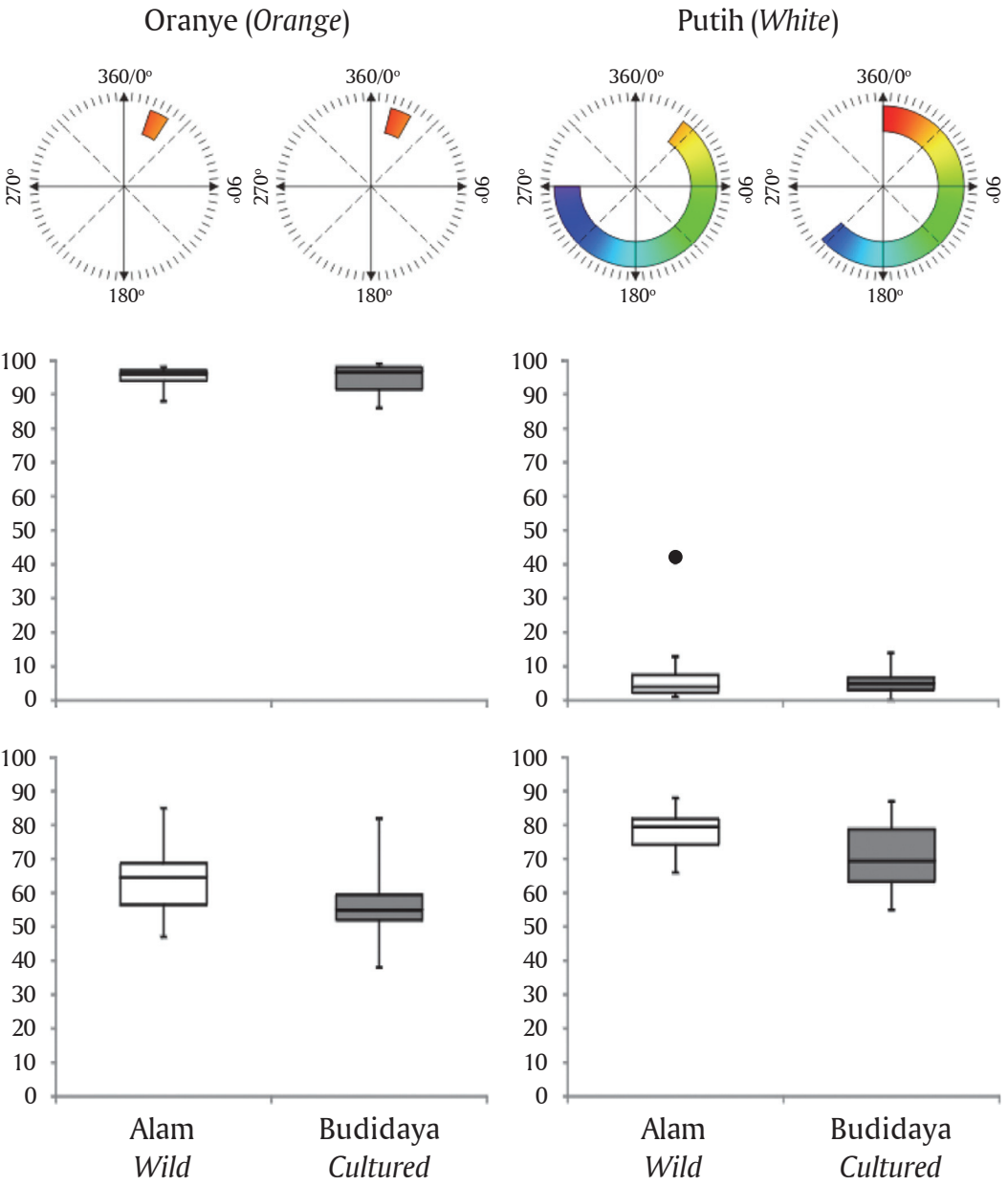

Gambar 4. Profil warna digital populasi ikan clown Biak alam dan budidaya

Figure 4. Digital colors profiles of wild and cultured populations of percula clownfish 
$\left(13^{\circ}-33^{\circ}\right)$. Jika kisaran tersebut diinterpretasikan dalam grafik hue pada Gambar 3, maka warna ikan $A$. ocellaris cenderung berwarna kuning, sedangkan ikan clown $A$. percula memiliki warna yang lebih oranye. Pada penelitian lainnya, Yasir \& Qin (2009) melaporkan rentang nilai hue ikan clown $A$. ocellaris yang diperoleh berkisar antara $33^{\circ}-36^{\circ}$.

Berdasarkan parameter saturation, variasi warna oranye populasi alam dan budidaya cenderung sama dengan persentase nilai digital yang tinggi. Sedangkan menurut parameter brightness, warna oranye populasi budidaya tampak lebih beragam (Gambar 4). Pada ikan cupang, warna digital oranye dikarakterisasi oleh nilai hue $11^{\circ}-37^{\circ}$, saturation $55 \%-97 \%$, dan brightness 53\%-95\% (Kusumah et al., 2011). Dalam color model HSB, warna digital oranye dikarakterisasi oleh nilai hue yang terletak di antara pertemuan warna digital merah dan kuning pada kisaran $0^{\circ}-45^{\circ}$. Tingkat kecerahan dan kepudaran warna oranye masing-masing ditentukan oleh nilai digital brightness dan saturation (Gambar 1A; Gambar 4). Semakin tinggi nilai brightness dan saturation yang dimiliki, maka warna oranye yang muncul semakin cerah. Secara visual, warna oranye yang ditampilkan ikan clown Biak populasi alam dan budidaya memiliki kisaran yang sempit dan spesifik terhadap jenis warna (hue) tersebut.

Jenis warna digital putih ikan clown Biak populasi alam dan budidaya memiliki panjang rentang hue yang sama. Berdasarkan Gambar 4, terlihat adanya pergeseran jenis warna putih. Populasi ikan clown Biak budidaya berada pada arah kisaran warna merah $\left(0^{\circ}\right)$ hingga biru $\left(229^{\circ}\right)$, sedangkan alam pada kisaran warna kuning $\left(36^{\circ}\right)$ hingga ungu $\left(270^{\circ}\right)$. Nilai saturation kedua populasi sama rendah. Sedangkan berdasarkan parameter brightness, populasi budidaya terlihat lebih beragam. Pada ikan cupang, warna digital putih dikarakterisasi oleh nilai hue $8^{\circ}-357^{\circ}$, saturation 6\%-28\%, dan brightness 57\%-90\% (Kusumah et al., 2011). Dibandingkan dengan ikan clown Biak, warna digital putih ikan cupang lebih bervariasi. Berbeda dengan warna hitam, nilai digital putih pada model warna HSB ditentukan oleh nilai brightness yang tinggi (bergerak mendekati $100 \%$ ) diikuti nilai saturation yang sangat rendah (bergerak mendekati 0\%) (Gambar 1A; Gambar 4). Sama seperti warna hitam, nilai hue tidak terlalu berpengaruh dalam visualisasi warna secara digital.

Berdasarkan pengamatan secara visual, jenis warna populasi alam dan budidaya ikan clown Biak menunjukkan karakter warna hitam, oranye, dan putih yang cenderung mirip. Perbedaan pada kisaran warna hue menghadirkan tampilan visual yang cenderung sama akibat adanya pengaruh dari variasi nilai digital saturation dan brightness (Gambar 4). Kondisi ini diduga terjadi karena ikan-ikan populasi alam telah beradaptasi pada kondisi lingkungan budidaya selama proses pemeliharaan sehingga tidak terlalu memperlihatkan lagi adanya perbedaan jenis warna dengan populasi budidaya. Selain faktor genetik dan hormonal, kualitas warna pada ikan dipengaruhi oleh banyak faktor lainnya mulai dari kualitas air (Lin et al., 2009), cahaya (Yasir \& Qin, 2009; Lin et al., 2009), warna wadah pemeliharaan (Doolan et al., 2008; Lin et al., 2009; Turne et al., 2009), kondisi pemeliharaan (Van der Salm et al., 2003), hingga nutrisi (Priyadi et al., 2007; Kalinowski et al., 2007; Yasir \& Qin, 2010). Berdasarkan Kusumawati et al. (2012), kondisi kualitas air di ruang indoor pemeliharaan ikan clown Biak di BBPBL Gondol memiliki suhu $28,28 \pm 0,38^{\circ} \mathrm{C}$; oksigen terlarut $5,03 \pm 0,22 \mathrm{mg} / \mathrm{L}$; salinitas $32,55 \pm 0,72$ ppt; pH 8,23 $\pm 0,06$; dengan iluminasi bawah dan permukaan masing-masing sebesar 209,33 $\pm 132,57$ lux dan $115,90 \pm 55,26$ lux.

\section{Persentase Penutupan Warna}

Penutupan jenis warna pada badan telah menjadi karakter yang menjadi target dalam pembentukan strain banyak komoditas ikan hias. Prinsipnya adalah bagaimana menghasilkan suatu strain warna dengan mengatur peningkatan atau penurunan persentase suatu jenis warna tertentu. Pada ikan cupang, peningkatan persentase penutupan warna telah digunakan untuk menghasilkan strain warna solid merah, biru, opaque, kuning, oranye, hitam, dan lain-lain (Kusumah et al., 2011). Pada ikan koi (Cyprinus carpio), upaya ini telah menghasilkan strain warna merah, kuning, putih, dan lainnya. Tidak hanya ikan cupang dan koi, pada ikan clown termasuk clown Biak juga telah dilakukan hal yang sama. Berbagai strain warna mulai dari black clownfish, platinum, hingga naked (Gambar 5), telah dihasilkan dari upaya selective breeding terhadap karakter penutupan warna tersebut.

Tabel 3 menunjukkan persentase penutupan setiap jenis warna badan clown Biak. Berdasarkan informasi tersebut dapat diketahui bahwa persentase penutupan warna clown Biak alam dan budidaya tertinggi masih ditunjukkan oleh warna oranye. Jika target yang ingin dicapai adalah strain black clownfish atau platinum (Gambar 5), maka nilai ini masih jauh dari harapan. Namun, jika target yang ingin dicapai berupa strain yang memiliki persentase penutupan oranye tinggi seperti strain misbar dan naked (Gambar 5), upaya ini diduga lebih sesuai dengan harapan.

Tabel 4 menunjukkan signifikansi ( $p$-value) perbedaan persentase penutupan setiap jenis warna pada populasi alam dan budidaya ikan clown Biak. Berdasarkan hasil uji-t pada Tabel 4, dapat diketahui bahwa 

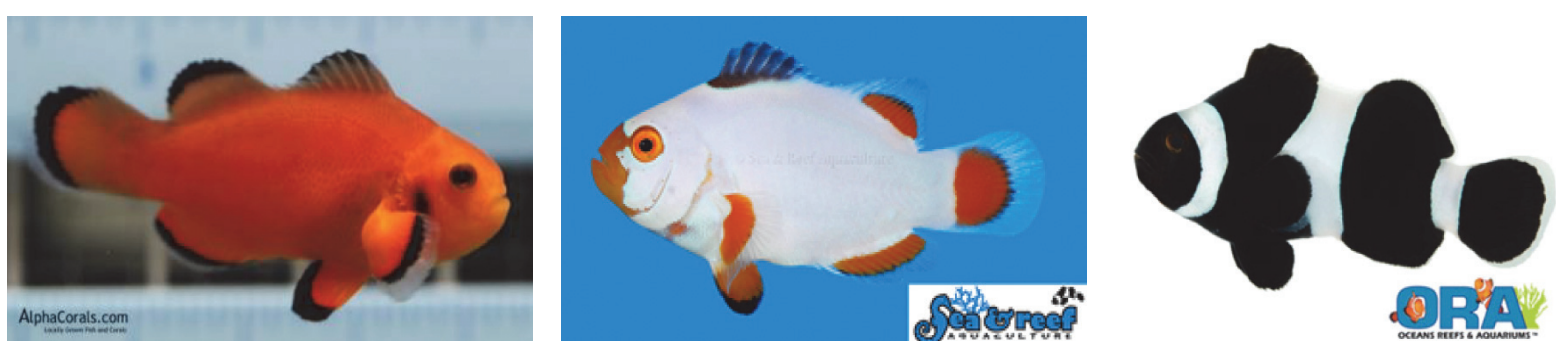

Gambar 5. Strain warna solid ikan clown Biak (kiri-kanan: naked, platinum, black clownfish)

Figure 5. Solid color strains of true percula clownfish (left-right: naked, platinum, black clownfish)

Tabel 3. Persentase penutupan warna badan ikan clown Biak populasi alam dan budidaya

Table 3. Colors covered percentage of wild and cultured populations of percula clownfish

\begin{tabular}{|c|c|c|c|c|c|c|c|}
\hline \multirow{2}{*}{$\begin{array}{l}\text { Jenis warna } \\
\text { Colors }\end{array}$} & \multicolumn{2}{|c|}{ Alam (Wild) } & \multicolumn{2}{|c|}{ Budidaya (Cultured) } & \multicolumn{3}{|c|}{ Strain warna (Color strains) } \\
\hline & $\begin{array}{l}\text { Kisaran } \\
\text { Range }\end{array}$ & $\begin{array}{c}\text { Rerata } \pm \text { SD } \\
\text { Mean } \pm S D\end{array}$ & $\begin{array}{l}\text { Kisaran } \\
\text { Range }\end{array}$ & $\begin{array}{c}\text { Rerata } \pm \text { SD } \\
\text { Mean } \pm S D\end{array}$ & $\begin{array}{l}\text { Hitam } \\
\text { Black }\end{array}$ & Platinum & Naked \\
\hline Hitam (Black) & $21-47$ & $34 \pm 7$ & $7-40$ & $21 \pm 10$ & 68-97 & $4-10$ & $3-8$ \\
\hline Putih (White) & $11-29$ & $22 \pm 5$ & $14-30$ & $23 \pm 4$ & $3-32$ & $69-80$ & $2-5$ \\
\hline Oranye (Orange) & $33-58$ & $45 \pm 7$ & $42-69$ & $57 \pm 8$ & $0-3$ & $16-21$ & $90-94$ \\
\hline
\end{tabular}

Tabel 4. Signifikansi perbedaan persentase penutupan warna ikan clown Biak populasi alam dan budidaya

Table 4. Significancy the percentage of color covered of wild and cultured populations of percula clownfish

\begin{tabular}{ccccccc}
\hline \multirow{2}{*}{$\begin{array}{c}\text { Jenis warna } \\
\text { Colors }\end{array}$} & \multicolumn{6}{c}{ P-value } \\
\cline { 2 - 6 } & HA & HB & PA & PB & OA & OB \\
\hline HA & & 0.00 & 0.00 & 0.00 & 0.00 & 0.00 \\
HB & & & $0.36^{\prime \prime}$ & $0.26^{\prime \prime}$ & 0.00 & 0.00 \\
PA & & & & $0.25^{*}$ & 0.00 & 0.00 \\
PB & & & & & 0.00 & 0.00 \\
OA & & & & & & 0.00 \\
OB & & & & & & \\
\hline
\end{tabular}

Keterangan (Note):

$\mathrm{HA}=$ Hitam alam (Wild black), $\mathrm{HB}=$ Hitam budidaya (Cultured black), PA = Putih alam (Wild white), $\mathrm{PB}=$ Putih budidaya $(\mathrm{Cul}$ tured white), $\mathrm{OA}=$ Oranye alam (Wild orange), $\mathrm{OB}$ : Oranye budidaya (Cultured orange)

Persentase penutupan warna tidak berbeda nyata $(\mathrm{p}>0,05)$ (The percentage of color covered are not significantly different $(p>0.05))$

seluruh persentase penutupan warna populasi alam dan budidaya umumnya berbeda nyata $(\mathrm{P}<0,05)$; kecuali persentase penutupan warna hitam budidaya dan putih (alam dan budidaya), serta persentase penutupan warna putih alam dan budidaya tampak tidak berbeda nyata $(P>0,05)$. Kondisi ini menunjukkan bahwa setiap penutupan warna umumnya ber- variasi baik berdasarkan jenis warna maupun populasinya, kecuali warna putih alam dan budidaya, serta hitam budidaya dengan putih (Gambar 3).

\section{KESIMPULAN DAN SARAN}

Keragaan warna populasi alam dan budidaya ikan clown Biak (Amphiprion percula) bervariasi berdasarkan pola, jenis, dan persentase penutupan warna dari strip hitam dan putih pada dasar badan yang berwarna oranye. Pengembangan strain warna ikan clown Biak populasi alam dan budidaya dapat diarahkan pada pembentukan strain misbar, picasso, spot (domino), dan onyx. Metode analisis gambar digital sangat potensial digunakan dalam analisis keragaan warna ikan hias, dengan keunggulan teknik berupa: (i) alat dan kelengkapan analisis mudah diperoleh dan murah, (ii) data yang dihasilkan bersifat obyektif, akurat, mudah dipahami, dan sesuai dengan persepsi penglihatan manusia, (iii) dapat dianalisis secara statistika dan dipertanggungjawabkan secara ilmiah, serta (iv) data gambar (foto) digital dapat disimpan dan dianalisis tanpa terpengaruh oleh waktu. Sedangkan kelemahan metode di antaranya adalah memerlukan tahap dan waktu yang cukup panjang sehingga perlu dikembangkan teknik yang lebih singkat dan cepat.

\section{UCAPAN TERIMA KASIH}

Penulis mengucapkan terima kasih kepada Kepala Balai Besar Penelitian dan Pengembangan Budidaya Laut (BBPPBL) Gondol dan Kepala Balai Besar Perikanan Budidaya Laut (BBPBL) Lampung atas izin dan bantuan teknis selama penelitian berlangsung. Secara 
khusus, penulis juga mengucapkan terima kasih kepada Ir. Ketut Maha Setiawati (BBPPBL Gondol), Rendy (BBPBL Lampung), I Made Agus Wijana Mertayasa, dan Asep Solihin (BPPBIH Depok) yang telah banyak membantu dalam pelaksanaan penelitian di lapangan dan Eni Kusrini, S.Si., M.Si. (BPPBIH Depok) atas koreksi awal naskah. Penelitian ini dibiayai oleh DIPA T.A. 2013.

\section{DAFTAR ACUAN}

Animal-world. (2015). True percula clownfish, Amphiprion percula orange anemone fish. http://animalworld.com/encyclo/marine/clowns/truepercula. php. Diakses 12 Juni 2015.

Barrierreefaquariums. (2014). Clownfish. http:// www.barrierreefaquariums.com/productcart/pc/ Clownfish-c96.htm. Diakses 31 Desember 2014.

Cerda-Reverter, J.M., Haitina, T., Schioth, H.B., \& Peter, R.E. (2009). Gene structure of the goldfish agouti-signaling protein: a putative role in the dorsal-ventral pigment pattern of fish. Endocrinology, 136(3), 1597-1610.

Colihueque, N., \& Araneda, C. (2014). Appearance traits in fish farming: progress from classical genetics to genomics, providing insight into current and potential genetic improvement. Front. Genet., 5(251), 1-8. doi: 10.3389/fgene.2014.00251.

Contextures Inc. (2013). Create a simple box plot box and whisker chart - in excel. https:/www. youtube.com/watch?v=ucWmfmXb1kk. Diakses 12 Juni 2015.

Doolan, B.J., Allan, G.L., Booth, M.A., \& Jones, P.L. (2008). Effects of cage netting colour and density on the skin pigmentation and stress response of Australian snapper Pagrus auratus (Bloch \& Schneider, 1801). Aquaculture Research, 39, 13601368.

Esanu, V.O., Gavriloaie, C., Oroian, I.G., \& Burny, P. (2015). Some considerations concerning the artificially colored aquarium fish trade. AACL Bioflux, 8(1), 116-121.

ExcelIsFun. (2009). Excel \& Statistics 39: Outliers \& box plot with median and mean. https:/www. youtube.com/watch?v=yflgOICZOxg. Diakses 18 Juni 2015.

Georgieva, L., Dimitrova, T., \& Angelov, N. (2005). RGB and HSV colour models in colour identification of digital traumas images. International Conference on Computer Systems and Technologies CompSysTech.

Harman, G. (1996). Explaining objective color in terms of subjective reactions. Philosophical Issues, 7, 117.

Kalinowski, C.T., Izquierdo, M.S., Schuchardt, D., \&
Robaina, L.E. (2007). Dietary supplementation time with shrimp shell meal on red porgy (Pagrus pagrus) skin colour and carotenoid concentration. Aquaculture, 272, 351-357.

Kondo, S., \& Shirota, H. (2009). Theoretical analysis of mechanisms that generate the pigmentation pattern of animals: Review. Seminars in Cell \& Developmental Biology, 20, 82-89.

Kusumah, R.V., Kusrini, E., Murniasih, S., Prasetio, A.B., \& Mahfudz, K. (2011). Analisis gambar digital sebagai metode karakterisasi dan kuantifikasi warna pada ikan hias. J. Ris. Akuakultur, 6(3), 381-392.

Kusumah, R.V., Permana, A., \& Priyadi, A. (2012). Variasi pola warna ikan botia (Chromobotia macracanthus Bleeker, 1852) serta prospek pengembangannya. Prosiding Forum Inovasi Teknologi Akuakultur 2012, hlm. 355-367.

Kusumawati, D. (2010). Kajian Gen Pengkode Pola Pigmen dan Profil Protein pada Ikan Badut Hitam (Amphiprion Percula). Tesis Master Pada Program Studi Pasca Sarjana, Jurusan Biologi FMIPA, Universitas Brawijaya. Malang, Unpublished.

Kusumawati, D., \& Setiawati, K.M. (2010). Profil pemijahan dan perkembangan morfologi larva dan yuwana ikan clown hitam (Amphiprion percula). J. Ris. Akuakultur, 5(1), 59-67.

Kusumawati, D., Permana, S., Setiawati, K.M., \& Haryanti. (2012). Peran gen AIM1 dan intensitas cahaya terhadap karakter pola pigmen ikan badut hitam (Amphiprion percula). J. Ris. Akuakultur, 7(2), 205-219.

Lin, Q., Lin, J., \& Huang, L. (2009). Effects of substrate color, light intensity and temperature on survival and skin color change of juvenile seahorses, Hippocampus erectus Perry, 1810. Aquaculture, 298, 157-161.

Mills, M.G., \& Patterson, L.B. (2009). Not just black and white: Pigment pattern development and evolution in vertebrates. Seminars in Cell \& Developmental Biology, 20, 72-81.

ORAfarm. (2014a). ORA domino (Amphiprion ocellaris). http://www.orafarm.com/products/fish /clowns/ domino/. Diakses 31 Desember 2014.

ORAfarm. (2014b). ORA naked ocellaris (Amphiprion ocellaris). http:/www.orafarm.com/ products/fish/ clowns/naked/. Diakses 31 Desember 2014.

Pederson, M. (2015). Part 2: Genetics; CLOWNFISH. Wilkerson's Lost Chapters. https://prezi.com/ fhcsu1p_2fzt/part-2-genetics-clownfishwilkersons-lost-chapters/. Diakses 22 April 2015 pukul 09:52 WIB.

Permen KP No. 25 Tahun 2014. Tentang Jenis baru ikan yang akan dibudidayakan. Kementerian Ke- 
lautan dan Perikanan. Jakarta.

Priyadi, A., Chumaidi, \& Musa, A. (2007). Pengaruh Spirulina sp. dan Astaksantin dalam formula pakan terhadap peningkatan kualitas warna benih Botia (Chromobotia macracanthus) asal Sumatera dan Kalimantan. Buku Ikan Hias Nusantara, hlm. 1-7.

Rasband, W. (2015). Software: ImageJ: Image Processing and Analysis in Java. National Institutes of Health, USA. http://imagej.nih.gov/ij/. Diakses 1 Mei 2015.

Rezende, F.P., Junior, M.V.V., de Andrade, D.R., Mendonça, P.P., \& dos Santos, M.V.B. (2012). Characterization of a new methodology based on the intensity of skin staining of ornamental fish with applications in nutrition. Journal of Agricultural Science and Technology, B2; 606-613.

Saltwaterfish. (2014). Ora black \& white false percula; aquacultured; misbar. http://www. saltwaterfish. com/product-ora-black-white-false-perculaaquacultured-misbar. Diakses 30 Juni 2014.

Sembiring, S.B.M., Setiawati, K.M., Haryanti, \& Wardana, I.K. (2010). Karakteristik genetik induk (F-0) dan turunannya (F-1) pada ikan hias laut clown (Amphiprion Percula) menggunakan marker RAPD (Random Amplified Polymorfism DNA). J. Ris. Akuakultur, 5(2), 183-190.

Sembiring, S.B.M., Setiawati, K.M., Hutapea, J.H., \& Subamia, W. (2013). Pewarisan pola warna ikan klon biak, Amphiprion percula. Jurnal Ilmu dan Teknologi Kelautan Tropis, 5(2), 333-351.
Setiawati, K.M., Gunawan, Yudha, H.T., Hutapea, J.H., \& Suarsana, K. (2011). Pengaruh shelter pada pemeliharaan benih ikan klon biak (Amphiprion Percula) di keramba jaring apung. Prosiding Forum Inovasi Teknologi Akuakultur 2011, jilid 1, hlm. 7985.

Turne, R.K., Sikes, A.L., Tabrett, S., \& Smith, D.M. (2009). Effect of background colour on the distribution of astaxanthin in black tiger prawn (Penaeus monodon): effective method for improvement of cooked colour. Aquaculture, 296, 129-135.

Van der Salm, A.L., Martinez, M., Flik, G., \& Bonga. S.E.W. (2003). Effects of husbandry conditions on the skin colour and stress response of red porgy, Pagrus pagrus. Aquaculture, 231, 371-386.

Yasir, I., \& Qin, J.G. (2009). Effect of light intensity on color performance of false clownfish, Amphiprion ocellaris Cuvier. Journal of the World Aquaculture Society, 30(3), 337-350.

Yasir, I., \& Qin, J.G. (2010). Effect of dietary carotenoids on skin color and pigments of false clownfish, Amphiprion ocellaris Cuvier. Journal of the World Aquaculture Society, 31(3), 308-318.

YongYue, C., HuiPing, Z., \& HuoSong, X. (2009). A study on the algorithm based on image color correlation mining. International Journal of Computer Information Systems and Industrial Management Applications (IJCISIM), 1, 279-286.

Wu, D., \& Sun, D.W. (2013). Colour measurements by computer vision for food quality control: A review. Trends in Food Science \& Technology, 29, 520. 